\title{
GASTRO-DUODENAL HAEMORRHAGE AND PERFORATION FOLLOWING CARDIOVASCULAR SURGERY IN CHILDREN*
}

\author{
BY \\ R. M. KONRAD \\ From Chirurgische Klinik der Medizinischen Akademie, Düsseldorf, Germany
}

Acute gastro-duodenal erosion and ulceration with haemorrhage and perforation are a rare yet serious complication following cardiovascular operations. Among 4,670 patients operated upon at the surgical clinic of Düsseldorf before April 30, 1960, gastro-duodenal erosions or ulcerations were seen in $129(3 \%)$ (Table 1) during the post-operative period. When the distribution of these patients is studied with regard to the kind of operation performed, a predominance of those surgical procedures that give the patient considerable stress, surgical or anaesthetic, becomes obvious. Operations for correction of coarctation of the aorta give the greatest trouble with an ulcer rate of $7 \%$. Next are operations using extracorporeal circulation for cardiopulmonary by-pass $(6 \%)$ and operations under general hypothermia $(4 \cdot 5 \%)$ (Table 2 ).

Children are far more liable to this complication than are adults. Among 129 patients who developed gastro-duodenal ulcerations following cardiovascular surgery, there were 68 children $(52.7 \%)$ below the age of 15 years. The preponderance of children becomes more obvious when the group of acquired cardiac disease, e.g. mitral disease, congestive pericarditis, is separated from the group of congenital heart disease. In the first group there are but few children under the age of 15 years, and in the latter group the ratio of children to adults is approximately $2: 1$.

The preponderance of children is obvious also when the group of patients undergoing cardiovascular surgery with the aid of extracorporeal circulation is analysed. Of this group, $39 \%$ were between the ages of 5 and 10 years, but half of all post-operative gastro-duodenal ulcers seen in patients undergoing surgery with extracorporeal circulation were observed in this age-group (Table 3). A similar distribution is found when the patients with coarctation of the aorta are analysed. Approxi-

- A paper read at a meeting of the British Association of Paediatric Surgeons in London, September 1962. mately $29 \%$ of these patients belong to the agegroup 0 to 15 years; again $50 \%$ of the post-operative gastro-duodenal ulcers in patients with coarctation were seen here (Table 4).

This complication of post-operative gastro-duodenal ulceration is usually ushered in by more or less pronounced upper abdominal pain. When severe gastro-duodenal haemorrhage occurs without haematemesis, sudden circulatory collapse followed by a drop in haemoglobin values is likely to be mistaken for haemorrhage from the site of the operation. However, when nausea and vomiting occur gastro-duodenal ulceration must be considered. When melaena occurs a day or two later, the diagnosis is almost certain. On the other hand, post-operative melaena and haematemesis may be due to bleeding from the nasopharynx, or due to haemorrhagic forms of diarrhoea in the course of necrotizing colitis and general infections.

Symptoms of post-operative gastro-duodenal ulceration in children usually occur between the second and the sixth post-operative day. Mortality from gastro-duodenal ulcers and erosions following cardiovascular surgery in children is $9 \%$ in our experience. Of 68 children with this complication, six died; in two of these death was due to free perforation of a gastric or duodenal ulcer after cardiac surgery under hypothermia, and in four it was due to uncontrolled haemorrhage.

Continuous measurements of the gastric juices were made during a variety of cardiovascular operations. They showed an increased acid and peptic activity, varying in extent and frequency in different surgical procedures. In general, surgical procedures using extracorporeal circulation or hypothermia showed a greater degree of acid and peptic gastric secretion than surgical procedures performed under conventional anaesthesia. It must be considered when looking at the low mean values that even during minor abdominal operations and during operations on the extremities, there may be 
TABLE 1

INCIDENCE OF POST-OPERATIVE GASTRIC AND DUODENAL ULCERS IN TOTAL NUMBER OF CARDIOVASCULAR OPERATIONS AT THE SURGICAL CLINIC OF DÚSSELDORF FROM 1947 TO APRIL 30, 1962

\begin{tabular}{c|c|c}
\hline No. of Patients & $\begin{array}{c}\text { No. of Patients with } \\
\text { Post-operative Gastric } \\
\text { and Duodenal Ulcers }\end{array}$ & Percentage \\
\hline 4,670 & 129 & $2 \cdot 8$ \\
\hline
\end{tabular}

TABLE 2

INCIDENCE OF POST-OPERATIVE CARDIOVASCULAR PATIENTS WITH GASTRIC AND DUODENAL ULCERS ACCORDING TO SURGICAL PROCEDURE AND ANAESTHESIA

\begin{tabular}{|c|c|c|c|}
\hline $\begin{array}{l}\text { Surgical Procedure } \\
\text { and Anaesthesia }\end{array}$ & $\begin{array}{l}\text { No. of } \\
\text { Patients }\end{array}$ & $\begin{array}{c}\text { No. of } \\
\text { Post-operative } \\
\text { Gastric and } \\
\text { Duodenal Ulcers }\end{array}$ & $\begin{array}{l}\text { Per- } \\
\text { centage }\end{array}$ \\
\hline $\begin{array}{l}\text { Mitral commissurotomy } \\
\text { Coarctation of aorta } \\
\text { Ligation of patent ductus } \\
\text { arteriosus } \ldots \\
\begin{array}{l}\text { Pericardectomy } \\
\text { Miscellaneous cardiovascular } \\
\text { operations }\end{array} \\
\begin{array}{l}\text { Operations with hypothermia } \\
\text { Operation with aid of extra- } \\
\text { corporeal circulation }\end{array}\end{array}$ & $\begin{array}{r}1,570 \\
312 \\
512 \\
145 \\
758 \\
870 \\
503\end{array}$ & $\begin{array}{r}27 \\
22 \\
9 \\
1 \\
3 \\
39 \\
28\end{array}$ & $\begin{array}{l}1 \cdot 7 \\
7 \cdot 1 \\
1 \cdot 7 \\
0 \cdot 7 \\
0 \cdot 4 \\
4 \cdot 5 \\
5 \cdot 6\end{array}$ \\
\hline
\end{tabular}

alterations in the gastric juices, which lie in the optimal digestive range of peptic activity and above (Tables 5 and 6). Apart from the fact that acid and peptic activity of the gastric juices is raised during surgical procedures, there may be a local deficiency in the resistance of the gastric wall, e.g. as a result of embolism, local vascular dis-

TABLE 3

POST-OPERATIVE GASTRIC AND DUODENAL ULCERS IN PATIENTS OPERATED ON WITH AID OF EXTRACORPOREAL CIRCULATION

\begin{tabular}{l|c|c|c|c|c|c|c|c}
\hline & & $6-10$ & $11-15$ & $16-20$ & $21-25$ & $26-30$ & $31-40$ & $41-60$ \\
\hline $\begin{array}{l}\% \text { patients } \\
\begin{array}{l}\% \text { post-operative } \\
\text { gastro-duo- } \\
\text { denal ulcers }\end{array}\end{array}$ & 50 & 50 & 18 & 11 & 14 & - & 7 & - \\
\hline
\end{tabular}

TABLE 4

POST-OPERATIVE GASTRIC AND DUODENAL ULCERS IN PATIENTS OPERATED ON FOR COARCTATION OF THE AORTA

\begin{tabular}{|c|c|c|c|c|c|c|}
\hline & \multicolumn{6}{|c|}{ Age-groups } \\
\hline & $0-10 \quad 11-15$ & $16-20$ & $21-25$ & $26-30$ & $31-40$ & $41-50$ \\
\hline$\%$ patients & $\begin{array}{c}14 \cdot 0 \\
29 \cdot 5\end{array}$ & $22 \cdot 7$ & $24 \cdot 2$ & $10 \cdot 6$ & $11 \cdot 5$ & $1 \cdot 5$ \\
\hline $\begin{array}{l}\% \text { post-operative } \\
\text { gastro-duo- } \\
\text { denal ulcers }\end{array}$ & $\begin{array}{c}0.1 \\
50 \cdot 0^{1}\end{array}$ & $27 \cdot 3$ & $13 \cdot 6$ & - & $9 \cdot 1$ & - \\
\hline
\end{tabular}

turbances during circulatory arrest, blood sludge, and fat and silicone embolization in hypothermia and extracorporeal circulation.

We have been able to show that aggregation of erythrocytes, the so-called 'sludge blood phenomenon', regularly occurs when the central body temperature is lowered to $34^{\circ} \mathrm{C}$. When the

TABLE 5

HIGHEST LEVEL OF TOTAL GASTRIC ACIDITY FOUND DURING OPERATION (\%)

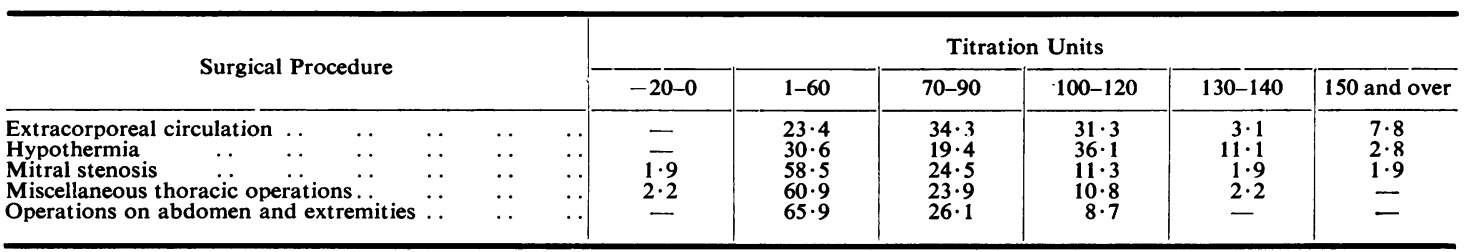

TABLE 6

HIGHEST LEVEL OF FREE GASTRIC ACIDITY FOUND DURING OPERATION (\%)

\begin{tabular}{|c|c|c|c|c|c|c|c|c|c|c|c|c|c|c|c|}
\hline \multirow{2}{*}{\multicolumn{4}{|c|}{ Surgical Procedure }} & \multicolumn{12}{|c|}{ Titration Units } \\
\hline & & & & $\begin{array}{c}-70 \\
\text { and } \\
\text { more }\end{array}$ & $\begin{array}{c}-60 \\
50\end{array}$ & $\begin{array}{c}-40 \\
30\end{array}$ & $\begin{array}{c}-20 \\
0\end{array}$ & $1-$ & $\begin{array}{c}30- \\
40\end{array}$ & $\begin{array}{c}50- \\
60\end{array}$ & $\begin{array}{c}70- \\
80\end{array}$ & $\begin{array}{l}90- \\
100\end{array}$ & $\begin{array}{c}110- \\
120\end{array}$ & $\begin{array}{c}130- \\
140\end{array}$ & $\begin{array}{c}150 \\
\text { and } \\
\text { more }\end{array}$ \\
\hline $\begin{array}{l}\text { Extracorporeal circulation } \\
\text { Hypothermia } \\
\text { Mitral stenosis . . } \\
\text { Miscellaneous thoracic op } \\
\text { Operations on abdomen a }\end{array}$ & $\begin{array}{ll}\cdots & \cdots \\
\cdots & \cdots \\
\text { ons } & \cdots \\
\text { xtremities }\end{array}$ & $\begin{array}{l}\cdots \\
\cdots \\
\cdots \\
\cdots\end{array}$ & $\begin{array}{l}\cdots \\
\cdots \\
\cdots \\
\cdots\end{array}$ & $\frac{1 \cdot 6}{\overline{6 \cdot 5}}$ & $\begin{array}{l}- \\
\overline{1 \cdot 9} \\
2 \cdot 3 \\
8 \cdot 7\end{array}$ & $\begin{array}{l}5 \cdot 6 \\
3 \cdot 8 \\
8 \cdot 7 \\
8 \cdot 7\end{array}$ & $\begin{array}{r}4 \cdot 7 \\
8 \cdot 3 \\
15 \cdot 1 \\
13 \cdot 0 \\
4 \cdot 3\end{array}$ & $\begin{array}{l}14 \cdot 1 \\
11 \cdot 1 \\
32 \cdot 1 \\
30 \cdot 4 \\
26 \cdot 1\end{array}$ & $\begin{array}{l}18 \cdot 7 \\
13 \cdot 9 \\
18 \cdot 7 \\
19 \cdot 6 \\
17 \cdot 4\end{array}$ & $\begin{array}{r}25 \cdot 0 \\
11 \cdot 1 \\
13 \cdot 1 \\
8 \cdot 7 \\
26 \cdot 1\end{array}$ & $\begin{array}{r}18 \cdot 7 \\
22 \cdot 2 \\
9 \cdot 4 \\
8 \cdot 7 \\
8 \cdot 7\end{array}$ & $\begin{array}{r}10 \cdot 9 \\
19 \cdot 4 \\
3 \cdot 8 \\
2 \cdot 2 \\
-\end{array}$ & $\begin{array}{l}3 \cdot 1 \\
8 \cdot 3 \\
1 \cdot 9 \\
- \\
-\end{array}$ & $\begin{array}{l}1 \cdot 6 \\
- \\
-\end{array}$ & $\begin{array}{l}1 \cdot 6 \\
- \\
- \\
-\end{array}$ \\
\hline
\end{tabular}


temperature is lowered further, this may lead to the temporary occlusion of capillary vessels; in rewarming, this phenomenon is fully reversible. Our investigations were carried out on the human conjunctiva during surgery under hypothermia. According to experimental studies in animals, carried out by Knisely, Bloch, Eliot and Warner (1947), the same phenomenon was observed in all organs.
In conclusion, a decrease in viscosity of the gastric juices, accompanying an increase in acid and pepsin production must be considered. All these factors may play a role in the development of post-operative peptic ulceration.

\section{REFFRENCE}

Knisely, M. H., Bloch, E. H., Eliot, T. S. and Warner, L. (1947). Sludged blood. Science, 106, 431. 